\title{
Using An Assessment Of Learning System To Integrate Core Content Across The Curriculum
}

\author{
Jean Rosales, Ph.D., University of North Carolina at Greensboro, USA \\ Jeff Sarbaum, Ph.D., University of North Carolina at Greensboro, USA \\ Michelle Sheran, Ph.D., University of North Carolina at Greensboro, USA \\ Stuart Allen, Ph.D., University of North Carolina at Greensboro, USA
}

\begin{abstract}
College and university programs are under increasing pressure to effectively measure and assess student performance, knowledge, and skills in their classes, majors and programs. We discuss how embracing this assessment charge can lead to a more cohesive and educational curriculum in which students and educators alike see the connections from one course to another as well as how a program's core learning objectives map throughout the curriculum. We discuss the importance of this in today's new reality of transfer students, online education, mega-classes and adjunct faculty. Lastly, we present an example of how we have begun to harness the reality of assessment to better integrate and harmonize an introductory course and an upper level course.
\end{abstract}

Keywords: Learning Assessment; Microeconomics; Curriculum Design

\section{INTRODUCTION}

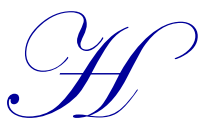

ow many of us in higher education have resisted the call for assessment of learning? How many have regarded it as a waste of time mandated by outsiders? We understand the backlash. After all, haven't we seen first-hand the downside of "high stakes" testing mandated by No Child Left Behind? How many of us have concluded that our students increasingly don't know how to think critically and instead have mainly learned how to memorize, regurgitate, and fill in the bubbles on standardized tests (Bracey, 2007; Houston, 2007; Moxey, 2005; Posner, 2007)? Yes, we understand why there is resistance to assessment of learning.

But isn't assessment just part of what we already do? Don't we know as educators that the value of assessment is determining whether our students are learning anything and so whether we are succeeding in teaching them? Yes, we do see a value in assessment. We just like to assess on our own terms.

This mentality misses one of the most valuable benefits of assessment. Systematic assessment at the program level can help achieve an integrated curriculum that promotes and measures critical thinking and problem solving skills. Program assessment helps us (and our students) connect the "dots" of core content and skills across our curriculum so that learning objectives can be meaningfully met and measured. It also ensures that we have necessary baseline information on the skills of the increasingly diverse student body we teach.

Sheran and Sarbaum (2012) introduced a six step guide for developing an effective assessment of learning system and demonstrated how this system was applied in a principles course. In this paper, we take the next step in designing an assessment of learning system for an entire program. We discuss how embracing the assessment process can bring faculty together to link course content, learning objectives and assessment measures throughout a program. We view this as essential for ensuring that we are out in front of and managing the assessment charge rather than just being dragged along. A well-designed assessment of learning system can help our students connect a program's core learning objectives throughout the curriculum and help us build a more cohesive curriculum. Just 
as learning is more than filling in the dots on a bubble sheet, assessment can and should be more than checking off items on an administrator's sheet. As we will discuss, effective assessment is particularly important in today's new reality of transfer students, online education, mega-classes and adjunct faculty. Finally, we demonstrate how we implemented this process by linking a principles course to a specific upper-level course.

\section{THE NEW REALITY}

Once upon a time, departments were small, and we got to know our colleagues and their teaching styles well. We could count on the fact that students taking our intermediate classes were coming to us directly from Dr. Jones's principles class, and we could be confident they had received a good grounding in the basics of supply and demand, elasticity, market structure, and production possibilities because we knew Dr. Jones always covered that material thoroughly.

Today, for better or worse, we're not in Kansas anymore. Departments have become larger to accommodate growing numbers of students and meet the economic necessity of achieving economies of scale, and Dr. Jones has now been joined in her task of teaching economic principles by Dr. Smith and Dr. Williams. Dr. Smith is a part-time faculty member who teaches a mega-course on principles to 200 students ${ }^{1,2}$; Dr. Williams never comes to campus because his courses are all taught online. ${ }^{3}$ They are all good, dedicated teachers, but we don't know them or their styles very well. We may believe they are all providing their students with the basics, but we don't have the same level of certainty that what they teach and what their students learn are the exact skills we need to take them to a higher level of understanding in more advanced courses.

Complicating matters further, today's students have many more alternatives available for earning credit toward their degrees than they did in the past. Many students take advantage of AP classes in high school to transfer in college credit. ${ }^{4}$ Others begin their college careers taking their beginning courses through community colleges before they transfer to schools where they plan to complete a bachelor's degree. ${ }^{5}$ Still others might enroll in the upper-level courses late in their careers; they've earned credit in the prerequisite principles classes, but nearly a decade might have passed since they took those classes, and the memory of "MC=MR" has long since failed.

\section{EFFECTIVE ASSESSMENT AND CURRICULUM DESIGN IN THE NEW REALITY}

We no longer have the same degree of confidence that students know what we want them to know when they come into the upper-level classroom. How else can we find out whether they are prepared if we don't test their knowledge coming in? Pre-testing in the manner recommended by Sheran and Sarbaum (2012) provides the teacher with objective information about what students remember from prerequisite courses. This information allows the teacher to fine-tune his or her presentations to review or even re-teach principles concepts in those areas where deficits in knowledge exist. Moreover, the process of designing, administering, and evaluating pre-tests helps us become more conscious of our own expectations about the knowledge and skills we want students to bring into the upper-level classroom.

\footnotetext{
${ }^{1}$ According to the latest report of the National Center for Education Statistics (NCES), full-time faculty accounted for $50.7 \%$ of all faculty in 2009, down from 57.5\% in 1999. U.S. Department of Education, National Center for Education Statistics, Higher Education General Information Survey (HEGIS), "Staff Survey" 1976; Integrated Postsecondary Education Data System (IPEDS), "Fall Staff Survey" (IPEDS-S:99); and IPEDS Winter 2009-10, Human Resources component, Fall Staff section. (This table was prepared August 2010.)

${ }^{2}$ NCES estimated the ratio of full-time equivalent (FTE) students to FTE faculty increased $7.38 \%$ between 1999 and 2009 with the ratio at public universities increasing $9.49 \%$ over that period.

${ }^{3}$ According to a 2011 report by NCES, the percentage of undergraduates who took any distance education courses rose from 16 percent in 2003-04 to 20 percent in 2007-08 (Table A-43-1).

${ }^{4}$ According to an NCES panel study following students for three years, approximately $20 \%$ of the beginning students under age 24 reported they had earned college credit through Advanced Placement tests or through college courses they took while still enrolled in high school (p. 13).

${ }^{5}$ Hossler et al. (2012) found approximately one-third of students in their national study transferred at least once during their college careers. The most common transfer pattern was from a two-year public institution to a four-year public institution.
} 
Not only must those teaching upper-level courses look to what is taught in preceding courses but these instructors must also consider how their courses reinforce and fit into the overall program objectives. This is illustrated in Figure 1, which shows how three such upper-level economics courses connect the dots between learning objectives in Principles of Microeconomics and overarching program learning objectives. We map one specific learning objective from Principles of Microeconomic (LO2) to three different field courses and then up to a program learning objective (LO1.1). ${ }^{6}$

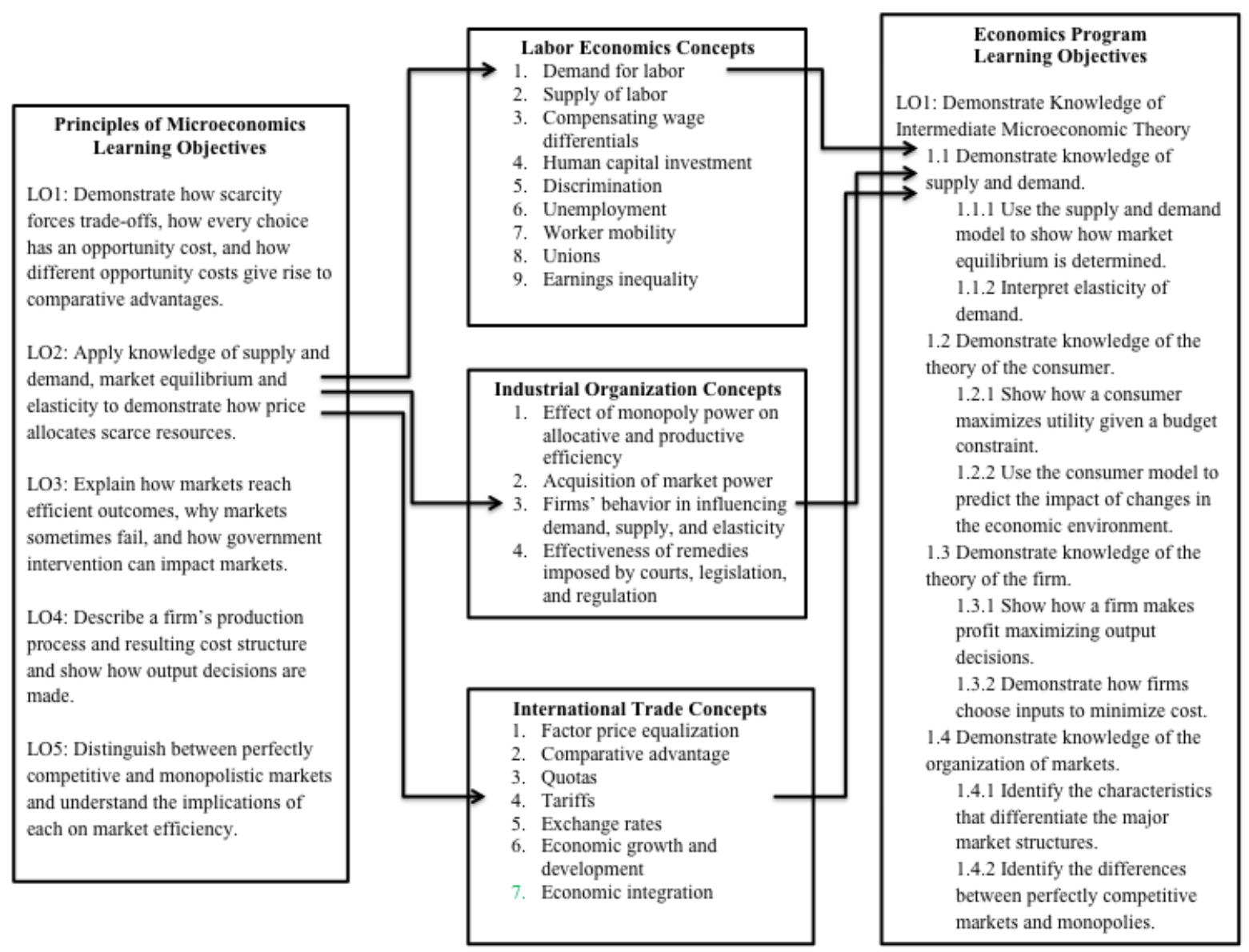

Figure 1: Illustration of a Curriculum Map

Program mapping helps us see that a program is a set of courses taken as a sequence that begins with an exposure to the basic principles of analysis and continues with coursework that requires students to apply these principles to a variety of situations. As students move through the sequence of courses, they become more adept at applying basic tools to different situations and understand that "thinking like an economist" is an activity that involves looking at a given real-world scenario and seeing that elements of the new scenario are conceptually parallel to cases they've seen before. This is the point at which students stop simply filling in the bubbles on the multiple choice answer sheets and begin to connect the dots between the knowledge they've already acquired and the knowledge they need to answer a specific question. On our end, connecting the dots throughout a program can best be accomplished if instructors identify the gaps, overlaps, and interconnections of the courses they are teaching and work with the instructors of courses that precede or succeed their own course.

This is where an effective assessment of learning system can help. Systematic assessment throughout a program helps faculty understand where and how each of their courses fits into the bigger picture of the curriculum.

\footnotetext{
${ }^{6}$ See Sheran and Sarbaum (2012) for a discussion of defining learning objectives for a specific course.
} 
Moreover, it promotes faculty coordination in defining course and program learning objectives, encouraging the dots to be connected from one course to the next. We have found that the process of designing assessments to track student progress leads to increased dialog among faculty, which is particularly important when designing courses that are meant to utilize the tools of a principles class and ultimately reach program objectives.

\section{AN EXPERIMENTAL DESIGN OF A CONNECTED COURSE}

In Fall 2012, one of the authors was asked to offer a course in Industrial Organization (IO). She was told that the department's Principles of Microeconomics course would be a prerequisite. Two of the other authors have many years of experience teaching both principles of micro and beginning field courses in labor and international economics. They provided her with copies of the pre- and post-tests they had used in their own research on assessment of learning and with the learning objectives for Principles of Microeconomics on which the tests were based.

After reading the recommendations in their earlier paper (see Sheran and Sarbaum 2012) and engaging in a series of discussions about using learning objectives to assess learning in the principles courses and at the program level, she decided to make two changes to the course she had already designed. First, she decided to administer a pre-test to her IO students to help her determine whether there were principles concepts she needed to review. Second, she added new sections to her IO presentations that made the connection between principles concepts and the new IO ideas more explicit.

The value of adding a pre-test is fairly obvious: as discussed above, the results of the pre-test would give her a better of sense of how well prepared her IO students were in basic economics concepts. The motivation for the second change, making the connections explicit, is less obvious and might best be explained with an example.

One of the learning objectives for the Principles of Microeconomics courses is:

LO2: Apply knowledge of supply and demand, market equilibrium and elasticity to demonstrate how price allocates scarce resources.

"Supply and demand" and "elasticity" are core concepts in IO. All firms hope to produce at a profit, and most would like to earn economic profits that are greater than the returns they would earn in a perfectly competitive market. To achieve that end, a firm will try to gain market power -- control over the quantities it will produce and the prices it can charge. The firm can engage in a number of activities that will enhance its market power. For example, it can invest in R\&D with a goal of inventing a new product or a new production process. Alternatively, it can advertise its product to affect consumers' willingness to purchase that product.

The fact that firms undertake these activities is obvious to anyone who studies IO. What is not so obvious is that each one of these activities relates back to affecting supply, demand, or elasticity.

If a firm succeeds in inventing and patenting a new product, it has a government-protected right to operate as a monopoly in that product. That is, it has affected the supply curve for its newly patented product by reducing the number of suppliers of that product to one. The supply curve has shifted to the left - a concept students were introduced to in principles.

Contrast that with a situation in which the firm has invented not a product but a new production process that is more efficient than the old process. This time, the firm has lowered its costs of production, which also translates into a shift in the supply curve, but one that is only available to firms using the new process. The firm with the new patented process has lower costs, which allow it to produce and sell at a price that is lower than that of its competitors. That firm's supply curve has shifted to the right - another principles concept associated with holding a patent, but one that is very different from the first case.

Anyone who studies Industrial Organization for any length of time becomes accustomed to recognizing these sorts of effects and how they translate into market outcomes. But students who are being introduced to these ideas for the first time may need help in recognizing that the new dot - patents- connects right back to the dots they already know - shifting supply and demand curves and changing elasticities. 
Consciously connecting those dots for students helps them see that supply and demand and elasticities are tools that can help them analyze and predict the effects of a firm's behavior in the market. At the same time, making the connection more explicit helps to reinforce the concepts they learned in their principles course, giving them firmer grounding in the basics of thinking like an economist.

All of the dots are there. Economics is a field in which more advanced concepts have their foundations in basic concepts. The challenge is finding the relationship between the advanced concept and its principles roots. Once you find that relationship, it is both easy and useful to point out to students how economics all ties together.

The goal of finding and connecting the IO dots to the principles dots led to re-working the presentation of the IO concepts for this course. Note that this did not involve changing or eliminating any of the material that had already been incorporated into the planned course. The only changes in the course material were statements, often one or two sentences, which connected the dots explicitly and tied the new material to that which was learned before.

\section{CONCLUSION}

Assessment of learning is part of our new reality in higher education. While we agree that assessment can and has been misused, it's time to acknowledge that a well-designed assessment system can have important benefits for course and curriculum design. The biggest lesson we learned from the design and implementation of the course described in this paper is that without a formal assessment system valuable faculty dialog would not have taken place. From this dialogue emerged three important benefits. First, it allowed us to identify the skills that students have coming into a course rather than simply assuming the prerequisite course did its job or choosing instead to reteach all the tools we would need. Second, it made us better appreciate the importance of stressing to students how the knowledge they acquire in one course can be applied in another. Third, it helped us see where and how each of our courses fits into the bigger picture of the curriculum and therefore led to a more cohesive curriculum.

\section{AUTHOR INFORMATION}

Dr. Jean K. Rosales is the graduate program administrator in the Department of Economics, University of North Carolina at Greensboro, NC, USA. Her research and teaching interests include helping students apply economic thinking to real-world situations. E-mail: jkrosale@uncg.edu

Dr. Jeffrey Sarbaum is a Senior Lecturer in the Department of Economics, University of North Carolina at Greensboro, NC, USA. His research interests include multimedia pedagogy, online teaching effectiveness, and assessment of learning. E-mail: jksarbau@uncg.edu (Corresponding author)

Dr. Michelle Sheran is a Senior Lecturer in the Department of Economics, University of North Carolina at Greensboro, NC, USA. Her research interests include household economics, foster care, assessment of learning, and economic education. E-mail: mesheran@uncg.edu

Dr. Stuart Allen is a Professor in the Department of Economics, University of North Carolina at Greensboro, NC, USA. His research interests include economic education and the effects of budget deficits on interest rates. E-mail: sdallen@uncg.edu

\section{REFERENCES}

1. Berkner, L. \& Choy, S. (2008). Descriptive summary of 2003-04 beginning postsecondary students: Three years later (NCES 2008-174). Washington, DC: National Center for Education Statistics, Institute of Education Sciences, U.S. Department of Education.

2. Bracey, G. W. (2007). The First Time 'Everything Changed.' The Phi Delta Kappan 89(2), 119-136.

3. Caviglia-Harris, J. \& Hill, B. (2010). Assessment plan and design: A model for enhancing instruction in economics courses. International Review of Economics Education, 9(1), 10-30. 
4. Evensky, J., \& Wells, M. (1998). Making a series of courses into a program: A case study in curriculum development. The Journal of Economic Education, 29(1), 72-80.

5. Gonzalez, J. (2012, Feb 28). A third of students transfer before graduating, and many head toward community colleges. The Chronicle of Higher Education. Retrieved from http://chronicle.com/article/AThird-of-Students-Transfer/130954/

6. Hossler, D., Shapiro, D., Dundar, A., Ziskin, M., Chen, J., Zerquera, \& Torres, V. (2012, February). Transfer \& mobility: A national view of pre-degree student movement in postsecondary institutions. National Student Clearinghouse Research Center. Retrieved from http://www.studentclearinghouse.info/signature/2/NSC_Signature_Report_2.pdf

7. Houston, P. D. (2007). The seven deadly sins of No Child Left Behind. The Phi Delta Kappan, 88(10), 744-748.

8. Moxey, T. (2005). Speaking my mind: How I learned to stop worrying and love standardized testing. The English Journal, 94(4), 16-17.

9. Myers, S.C., Nelson, M.A., \& Stratton, R.W. (2009). Assessing an economics programme: Hansen proficiencies, ePortfolio, and undergraduate research. International Review of Economics Education, 8(1), 87-105.

10. Myers, S.C., Nelson, M.A. \& Stratton, R.W. (2011). Assessment of the undergraduate economics major: A national survey. The Journal of Economic Education, 42(2), 195-199.

11. Mytelka, A. (2008, Jul 30). Transfer students make up almost 20\% of 4-year colleges' enrollments, report says. The Chronicle of Higher Education. Retrieved from http://chronicle.com/article/Transfer-StudentsMake-Up/41378

12. Posner, D. (2004). What's wrong with teaching to the test? The Phi Delta Kappan, 85(10), $749-751$.

13. Sheran, M., \& Sarbaum, J. (2012). Developing an assessment of learning process: The importance of pretesting. American Journal of Business Education.

14. U. S. Department of Education. National Center for Education Statistics. (2011). The condition of education 2011 (NCES 2011-033), Table A-43-1. Distance Education in Higher Education (Indicator 432011). Available at http://nces.ed.gov/programs/coe/indicator_dhe.asp

15. U.S. Department of Education, National Center for Education Statistics, Higher Education General Information Survey (HEGIS), "Staff Survey" 1976; Integrated Postsecondary Education Data System (IPEDS), "Fall Staff Survey" (IPEDS-S:99); and IPEDS Winter 2009-10, Human Resources component, Fall Staff section.

16. U.S. Department of Education, National Center for Education Statistics, Higher Education General Information Survey (HEGIS), Employees in Institutions of Higher Education, 1970 and 1972, and "Staff Survey" 1976; Projections of Education Statistics to 2000; Integrated Postsecondary Education Data System (IPEDS), "Fall Staff Survey" (IPEDS-S:87-99); IPEDS Winter 2001-02 through Winter 2009-10, Human Resources component, Fall Staff section; and U.S. Equal Employment Opportunity Commission, Higher Education Staff Information Survey (EEO-6), 1977, 1981, and 1983. (This table was prepared August 2010.)

17. Walstad, W.B. (2001). Improving assessment in university economics. The Journal of Economics Education, 32(3) 281-294. 